\title{
Review: Educación y divulgación del patrimonio arqueológico
}

\section{Eduardo CERRATO-CASADO}

Academia de Historia de la Iglesia en Andalucía Centro de Magisterio Sagrado Corazón de la Universidad de Córdoba ecerrato@uco.es

Ruiz Osuna, A.; Medina Quintana, S. and Pérez Naranjo, L. M. (Coords). 2020.

Educación y divulgación del patrimonio arqueológico: La socialización del pasado como reto para el futuro. Granada, Editorial Comares.

220 pages

ISBN: 9788490459041

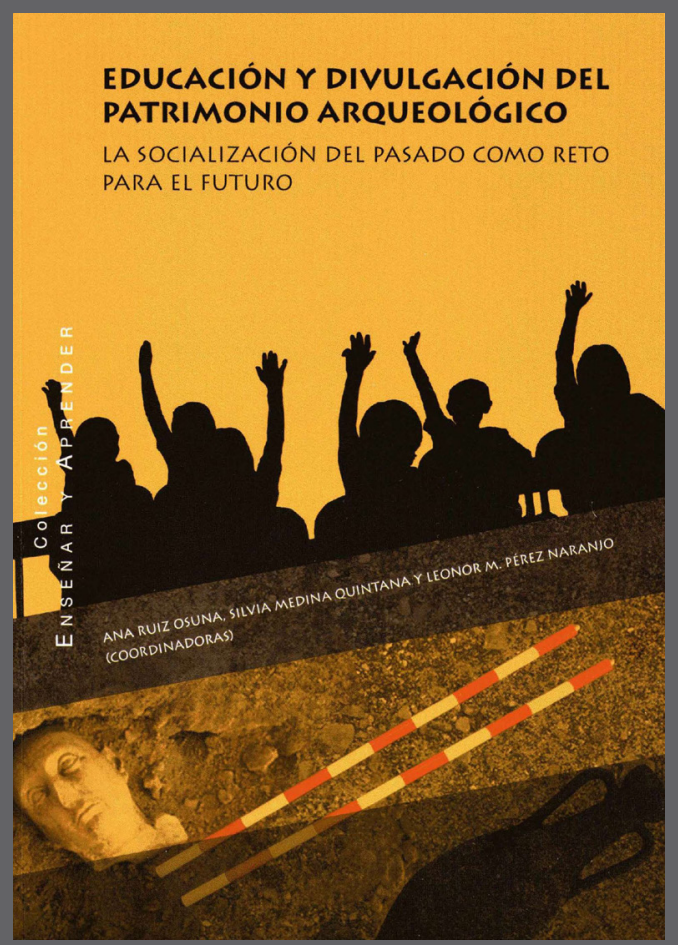

AP: Online Journal in Public Archaeology - Volume 11 - ISSN: 2171-6315

Cerrato-Casado, E. 2021. Review: Educación y divulgación del patrimonio arqueológico. AP: Online Journal in Public Archaeology 11, r1-r5.

DOI: 10.23914/ap.v11i0.324 


\section{r2 :: AP Journal v.11 :: REVIEW}

A popular proverb states 'Don't play with your food'. This maxim that not only concerns those of us who have the immense fortune of dedicating our working hours (and more if possible) to the noble discipline of archaeology and historical research. If anything is really clear to us, it is that Heritage (from the perspective of investigation, safeguard and management) is more than the 'food' of a couple of professors and four tourist guides, but of many thousands whose income depends on it essentially through tourism. In fact, tourism in Spain in 2019 before the pandemic yielded 154,487 million Euros to the economy, representing 12.4\% of its GDP. In fact, dear reader, please reflect on what drives you to go on vacation? And what leads you to choose one tourist destination over another? The response is simple: diversity. It represents a search for something that is unknown where you reside, something unique and unrepeatable that is only found at a particular destination, a unique setting offering an aesthetic or gastronomic experience that otherwise would not be worth the visiting. This book under review delves precisely into the question of this diversity we seek when traveling as it is Heritage (either material or intangible, artistic, monumental, archaeological or natural) that gives an identity to each city, each community. Heritage renders them different from other neighbouring cities. From a material point of view, Heritage is what attracts tourists and, even more, from a sentimental point of view, it is what offers signs of identity to locals. Thus in the end we are not only talking about 'things to eat'.

But Heritage requires maintenance. Both society and administrations must learn to care for it (or at least not destroy it) to guarantee its continuity for future generations. Heritage professionals have sold out if they fail to apply the virtuous circle of managing it. It is only through a correct dissemination of research that we can achieve social support (awareness and financial commitment) to re-finance research and dissemination. The authors of this volume of proceedings whose title translates as Education and Disseminating Archaeological Heritage: Socialisation of the Past as a Challenge for the Future have understood it in this manner and initiated work with the clear objective that society participate in its management and protection to guarantee its conservation. For this reason, this book is, in a certain manner, a code for good Heritage practices as it gathers a series of interdisciplinary experiences (Archaeology, Didactics and Tourism) targeting this objective. In fact, the training and professional dedication of the coordinators of these proceedings is a declaration of intent in terms of interdisciplinarity. The coordinators are in fact three young women with brilliant academic careers in disciplines which although different are complementary: archaeology (Ana Ruiz Osuna), didactics of social sciences (Silvia Medina Quintana) and tourism (Leonor Pérez Naranjo).

This monograph likewise does not spring out of the blue and is not improvised, but stems from a long trajectory of heritage dissemination and, more specifically, the research project PATTERN: (P)atrimonio (A)rqueológico, Nuevas (T)ecnologías, 
(T)urismo, (E)ducación y (R)entabilización social: un (N)exo necesario para la ciudad histórica (Ref. HAR2015-68059-C2-1- R) directed by Desiderio Vaquerizo Gil between 2016 and 2019, and funded by of the State Research Programme of the Ministry of Economy and Competitiveness. The Sisyphus Research Group (PAIDI HUM236) of the University of Córdoba stands out throughout the last decade as the main agent of archaeological dissemination of the Province of Córdoba. The group organises children's workshops, conference cycles, archaeological excursions and expeditions, historical re-enactments workshops, etc., through the renowned scientific culture project entitled Archeología Somos Todos, (We are all Archaeology) which was awarded, among other prizes, a special mention from the Europa Nostra jury (2014) of the European Union.

The monograph comprises a prologue by Prof. Vaquerizo himself and 14 contributions by different professionals from the fields of Didactics, Tourism and Public Archaeology who present their respective experiences of Heritage dissemination. José Antonio Fernández from the field of didactics (University of Córdoba) theorises on the need for proper heritage training for primary school teachers (pp. 1-19); Belén Calderón (University of Malaga) resorts to cases of contemporary Malaga graffiti as a tool to foment heritage education for students of secondary schools (pp. 21-36); Roberto García-Morís (University of La Coruña), Silvia Medina and Montserrat Reina (University of Córdoba) analyse, from a didactic point of view, twelve literary resources for children dedicated to the heritage of Córdoba (pp. 37-52); Luis Alberto Polo (Rey Juan Carlos University) delves into the role of ICTs (virtual reproductions and 3D prints) as didactic resources (pp. 53-64); Silvia Medina and Miguel Jesús López (University of Córdoba) share their thoughts on applying the gender perspective, a notion currently in vogue for conveying Cordoba's archaeological heritage in primary schools (pp. 81-95). The final article concerning didactics is by Rubén Pérez, Silvia del Mazo and Francisco José Rufían, the main promoters of the Pequeños Arqueólogos (Little Archaeologists) project. It relates their experiences at the head of a business initiative that offers programs in Castilla-La Mancha aimed at educational centres, parks and archaeological sites, museums, and public and private institutions consisting of workshops, activities, resources and quality teaching materials linked to Historical, Archaeological and Craft Heritage (pp. 96-114).

The analysis of the phenomenon of archaeological tourism leads to two compelling and valuable contributions that resort to the tools of demoscopy. The first, by Leonor Pérez Naranjo (University of Córdoba), delves into the responses of more than 500 individuals potentially interested in archaeotourism. Its aim is to identify their intentions, preferences and tastes, to develop a specific, complete and valuable profile of this type of tourist (pp. 127-140). The second article is by $\mathrm{M}^{\mathrm{a}}$ Isabel Rodríguez Zapatero (University of Córdoba) who resorted to the visitors of the Archaeological Museum of Córdoba as a sample to clarify which attributes and 


\section{r4 :: AP Journal v.11 :: REVIEW}

areas to prioritise and where to invest resources to improve levels of satisfaction (pp. 141-152). It is more than desirable that the conclusions gleaned by these authors not fall on deaf ears and taken into consideration by the different administrations.

The next contribution, by Carlos A. Hiriart (Universidad Michoacana de San Nicolas Hidalgo), a key international spokesperson, advances research on heritage conservation of minor archaeological sites in Mexico and their management as resources of tourism through a focus on the site of Tzintzuntzan in Michoacán. He warns of the necessity to rethink collaborative strategies so as to involve all levels of the administration and insists on the need of participation of the community (pp. 153-164). Nuria Huete and Miguel Ángel Valero (University of Castilla La Mancha) in the twelth contribution claim Archaeological Heritage as a factor serving the local development of the region of La Alcarria (Cuenca) highlighting its dynamic potential in an area suffering from a depressed economy and declining population (pp. 165-177).

The two contributions dedicated to experiences in the field of Public Archaeology merit special mention above all because of the novelty of their inclusion in a monograph in Spanish. Public Archaeology is in fact a very recent discipline in Spain and still in the process of defining itself'. It is a concept with origins dating back to about 50 years in the United Kingdom that has yet to receive recognition in Spain². It can be defined as a branch of Archaeology charged with analysing the relationships between archaeology and current society in order to improve and facilitate a mutual understanding between the two, a task that has not always been possible. In this sense, most of the Public Archaeology initiatives undertaken by the Sisyphus Research Group (including this monograph) ${ }^{3}$ are playing a pioneering role within Spanish borders. This is very much in tune with the research by Jaime Almansa of the CSIC who can be considered the father of Spanish Public Archaeology 4 .

The first of these Public Archaeology contributions, authored by Belén Vázquez (University of Córdoba), recalls by resorting to the example of the Arab baths in the city of Córdoba, the role 3D reconstructions can play in facilitating

\footnotetext{
1 In reality the Didactics of archaeological heritage and studies on Archaeotourism when taking this definition into account should each fall into the field Public Archaeology as they concern society as a whole. However, due to their specificity, each constitute independent thematic groups.

2 The Mediterranean world in this aspect, as in many others, lags behind that of the Anglo-Saxons as the publication of contributions such as those of this monograph is a novelty here. Moreover, many British and North American universities offer an MA in Public Archaeology since about a decade.

3 Certain recent milestones worth mentioning are the publication of this monograph followed by the celebration of the PATTERN international congress, November 19-21, 2019, and the 1st Fair of Archaeological Heritage Diffusion (November 22-23, 2019). There is likewise the creation of a digital viewer of the archaeological itineraries of Córdoba (http://www.arqueocordoba.com/rutas/) and a Geographic Information System regarding the Archaeological Excavations of Córdoba (SIGEAC) (http://www.arqueocordoba.com / sigeac /).

4 I apologise to Jaime Almansa if, due to his title, someone were to assume him to be older than he actually is. Along these lines, there is also the research of J. Santacana in didactics and heritage education and J. J. Tresserras in archaeotourism. The influence of these pioneers is very present in the different articles of this monograph.
} 


\section{:: Cerrato-Casado - Review: Educación y divulgación... :: r5}

the transmission of Heritage (pp. 65-80). The second authored by Rafael Blanco (University of Córdoba), serving to close the monograph, once again refers to a case in Córdoba, specifically the restoration of the Caliphal Minaret of San Juan de los Caballeros. This site in fact serves its author to theorise as to the nature of the relationship between society and its historical-archaeological heritage (pp. 192-220).

Halfway between Public Archaeology and Archaeotourism is the project presented by Marta Gómara, Carolina Ruiz and Enrique Rojas (Asociación Cultural Amigos de Cascante Vicus) (Friends of Cascante Vicus Cultural Association) carried out in the town of Cascante (Navarra) (pp. 179-191). Along these lines is also the constribution by Miguel Serra, Eduardo Porfirio (University of Coimbra) and Rafael Ortiz (University of Seville) relating their diffusion experiences of the last 10 years in the framework of the excavation of the Late Bronze Age fortified settlement of Outeiro do Circo (Beja, Portugal) (pp. 115-126). Although each of the two dissemination projects target residents of their territories (local visitors), they no doubt ultimately intend to attract foreign tourists that are essential to promote the region's sustainable development.

In short, and giving free rein to our most poetic side, this monograph forms part of the prow of an icebreaker entering into the tempestuous seas of Spanish Public Archaeology. It not only incorporates articles that theorise on certain aspects that must be taken into account when disseminating Heritage, but also collects practical experiences that should inspire future actions. A final warning to the readers. If you form part of the select group of brilliant academics who deem diffusion to the public as a shameful activity unworthy of scientists, you still have time to reconsider. Likewise, there is still time for public servants who view diffusion as a waste of budget to correct their myopia and put on their glasses and see that these are long-term investments whose fruits are ripening in cities such as Mérida and Tarragona and, more recently, Cartagena. Don't lose hope! And let's not let this opportunity pass! 
